\title{
Research
}

\section{Regional Variation in Non-Timber Forest Product Harvest Strategies, Trade, and Ecological Impacts: the Case of Black Dammar (Canarium strictum Roxb.) Use and Conservation in the Nilgiri Biosphere Reserve, India}

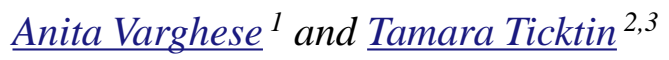

\begin{abstract}
Millions of people worldwide depend on the harvest of non-timber forest products (NTFP) for their livelihoods, and the importance of understanding the complex relationships between NTFP harvest and conservation is increasingly recognized. This study employs a cross-disciplinary, regional approach to identify some of the links between patterns of harvest, trade, and conservation of one of South India's most heavily harvested resins, Canarium strictum Roxb. (Burseraceae), or black dammar. We focus on indigenous communities in the Nilgiri Biosphere Reserve (NBR) and ask: How is $C$. strictum tapped and is there variation across communities? How is $C$. strictum resin sold and bought, and what trade routes are involved? What are the impacts of tapping on $C$. strictum trees and population structure? We carried out interviews and focus-group discussions with harvesters in eight villages in three different regions, and with buyers and traders inside and outside of the NBR. We also established twenty-two $20 \times 20 \mathrm{~m}$ plots to document population structure. Three broad resin-harvest strategies were identified: collection from natural fissures, tapping using incisions, and tapping using incisions and fire, each practiced in a different region. However, within each strategy there was large variation in tapping frequency and timing, tenure practices, and resin quality. The loss of tree tenure in some areas has led to a higher frequency of tapping and to the production of lower quality, lower value resin. Factors driving changes in both tenure and tapping strategies include rising commercial demand and value, pressure from outside harvesters, changes in livelihood strategies, and habitat destruction. Tapping leads to elevated mortality of $C$. strictum adults, with firetapping have a greater negative impact than tapping with no fire. The combination of social and ecological approaches used here provides insight on strategies for better conservation of $C$. strictum. These include the promotion of tapping and sale of only high-grade resin-which is a good indicator of sustainable harvest - enrichment planting to help address some of the underlying causes of overharvest, and sparing of some trees for increased reproduction.
\end{abstract}

Key Words: Canarium strictum; conservation; India; non-timber forest products; resin; Western Ghats

\section{INTRODUCTION}

Millions of people worldwide depend on the harvest of non-timber forest products (NTFP) for their livelihoods (Vedeld et al. 2004), and the importance of understanding the complex relationships between NTFP harvest and conservation is increasingly recognized (e.g., Ticktin 2004, Kusters et al. 2006, Belcher and Schreckenberg 2007). This comes as a result of various factors, including concern about overexploitation and interest in the promotion of NTFP harvest as a conservation and development strategy (e.g., Nepstad and Schwartzman 1992, Cunningham 2001, Secretariat of the Convention on Biodiversity (SCBD) 2001). Although there is now a growing body of literature on the ecological impacts of NTFP harvest, most studies have focused on single NTFP populations and human communities (see review by Ticktin 2004). This is problematic because the impacts of harvest can vary according to local harvest strategies, which can be highly variable across communities (Nantel et al. 1996, Ticktin et al. 2002, Ghirmire et al. 2005). Further, local harvest strategies are influenced by 
the socioeconomic, political, and ecological contexts of harvest (e.g., Paudel and Wiersum 2002, Ghirmire et al. 2004, Kusters et al. 2006). Ignoring the potential variation in harvest strategies and their drivers can lead to conclusions about sustainability that may not be optimal or even relevant in some contexts (Ticktin and Johns 2002). For the many NTFP species that are harvested over large and diverse areas, a larger-scale, comparative approach that considers variation in both social and ecological factors is, therefore, necessary for assessing sustainability and some of the factors that may influence it.

We employ a cross-disciplinary comparative approach to identify some of the links between patterns of harvest, trade, and conservation of one of South India's most heavily harvested resin trees, Canarium strictum Roxb. (Burseraceae). Canarium strictum yields the resin known as black dammar, and is harvested from the moist deciduous and evergreen forests of the Nilgiri Biosphere Reserve (NBR) and other parts of India's Western Ghats, a biodiversity hotspot (Myers et al. 2000). It has a long history of harvest for medicinal and spiritual uses (Ravikumar and Ved 2000), but most commercial harvest today is for the manufacture of incense, varnish, and matchsticks (Augustine and Krisnan 2006). The NBR crosses over parts of three Indian states that have differing regulations on black dammar harvest, and harvesters come from different indigenous ethnic communities with diverse livelihood strategies (Keystone Foundation 2007).

C. strictum is one of various tree species commercially harvested for dammar throughout South and Southeast Asia. Dammar is a term applied to a variety of hard resins that are soluble in turpentine and other organic solvents and used mostly for the manufacture of varnish, lacquers, and paints. With the exception of Canarium species, most dammar is extracted from members of the Dipterocarpaceae (Langenheim 2003). Despite their economic importance to local communities, very little information is available on the ecological impacts of tapping dammar or other types of resin from wild populations (see review by Ticktin 2004). The little research that does exist suggests that heavy tapping can have significant negative impacts on populations. For example, resin tapping of another member of the Burseraceae, Boswellia papyrifera, significantly reduces reproductive output and heavy tapping is thought to be a cause of population decline (Gebrehiwot et al. 2003, Rijkers et al. 2006). Resins and other exudates are made up mostly of carbonbased compounds and are thought to play an important role in plant defense. They may seal up wounds and prevent their desiccation, protect against attack by insects and fungi, and prevent further injury though decay (Phillip and Croteau 1999, Langenheim 2003). It is hypothesized that, in heavily tapped trees, investment in resin production can lead to decreased allocation of carbon resources to growth and reproduction (Rijkers et al. 2006).

In the case of $C$. strictum, several authors have expressed concerns that populations are disappearing due to tapping practices (Kannan 1992, Augustine and Krishnan 2006), and C. strictum is considered vulnerable in South India (Ravikumar and Ved 2000). However, there is very little information available on the nature, extent, or patterns of $C$. strictum harvest and trade in the NBR or elsewhere, or of the impacts of tapping C. strictum populations. Indeed, despite the dependence of millions of people on the collection of NTFP species in India, and of the wide diversity of species harvested, to date there is still little research on harvest patterns and trade of Indian NTFP and their ecological impacts. The few studies that have been done have illustrated that some types of harvest have negatively affected the structure and dynamics of populations (Murali et al. 1996, Kala 2000, Sinha and Bawa 2002, Sinha and Brault 2005, Muraleedharan et al. 2005) and led to changes in plant communities (Murali et al. 1996, Ganeshaiah et al. 1998). These findings point to the great need for more work in this area, especially for those wild-harvested NTFP such as C. strictum, whose populations are reported to be declining.

In this study, we addressed the following questions:

1. How is C. strictum tapped in the NBR, and how do tapping practices vary across communities? We identify differences in harvest methods and patterns, resin quality, tenure regimes, and traditional knowledge. We also document variation in livelihood strategies and in threats to local forests.

2. How is $C$. strictum resin sold and bought throughout the NBR, and what are the resin trade routes?

3. What are the impacts of tapping on C. strictum trees and population structure, and do these vary according to different tapping practices? 
4. Based on the above, what social and economic factors influence $C$. strictum tapping strategies and their potential for sustainable harvest?

We draw on our results to provide recommendations for better conservation of $C$. strictum populations.

\section{METHODS}

\section{Study Site}

The NBR is part of the Western Ghats chain of mountains of the Indian peninsula. It lies between $10^{\circ} 45^{\prime} \mathrm{N}$ to $12^{\circ} \mathrm{N}$ and $76^{\circ} \mathrm{E}$ to $77^{\circ} 15^{\prime} \mathrm{E}$ with a total area of $5520 \mathrm{~km}^{2}$ spread across the three states of Karnataka, Kerala, and Tamil Nadu (Fig. 1). Altitude within the NBR varies from $250 \mathrm{~m}$ to 2650 $\mathrm{m}$, and the reserve encompasses a diversity of vegetation types, ranging from tropical evergreen to thorny scrub (Prabhakar 1994). The NBR was the first biosphere reserve established India, declared in September 1986 by the UNESCO Man and Biosphere program. There are six protected areas within the reserve and still larger tracts of forests that lie outside of these, known as Reserve Forests.

The NBR is also home to more than 20 different indigenous (termed adivasi in India) communities, whose livelihoods are intricately linked with the non-timber forest resources of the NBR's Reserve Forests (Keystone Foundation 2007). Only adivasi communities retain the rights to harvest and trade NTFP from the NBR's Reserve Forests. The list of NTFPs permitted to be harvested is stipulated by the state forest departments, but no collecting of NTFPs is permitted within the six protected areas. Most of the indigenous communities in the NBR are either forest dwellers who practice shifting agriculture or hunter gatherers, and the total indigenous population in the NBR is estimated to be about 200000 (Keystone Foundation 2007).

\section{Study Species}

Canarium strictum is a large canopy tree with bipinnate leaves that is distributed across parts of India, Myanmar, and Yunnan province, China. It can grow up to about $40 \mathrm{~m}$ tall and is found in moist deciduous to semi-evergreen forests at altitudes ranging from about $750 \mathrm{~m}$ to $1400 \mathrm{~m}$ (Ravikumar and Ved 2000). Trees are polygamous (Gamble 1935) and flowers are insect pollinated (Tambat et al. 2005). Fruits are ovoid or ellipsoid drupes with one to three seeds. Seed predation has been reported to be very low (1\%) (Ganesh and Davidar 2005). Canarium strictum sheds its leaves during the months of December and January, and it is reported to be a late-secondary forest species (R. Ganesan, pers. comm.). To our knowledge, there is no published information on the demography of $C$. strictum and information on growth rates, size of first reproduction, and resin yields is lacking.

Black dammar has been used traditionally to cure numerous ailments, including rheumatism, coughs, asthma, epilepsy, syphilis, hernia, fever, chronic skin diseases, and hemorrhage (Ravikumar and Ved 2000). Although no studies have been carried out on the synthesis of black dammar, synthesis of most constitutive resin in Canarium species is thought be produced in the bark as a result of wounding (Langenheim 2003). Canarium strictum was also harvested for its timber in the past, but logging was banned over 30 years ago and has stopped since then. Unlike many other Canarium species, the fruits of $C$. strictum are not edible.

The harvest of black dammar is permitted for trade in Kerala, but in Tamil Nadu, as a conservation measure, harvest is permitted only for personal or home use.

\section{Selection of Study Sites within the NBR}

Areas where $C$. strictum is present and/or harvested in the NBR were identified in part of a larger project to map areas where adivasis collect forest produce from Reserve Forests. Specifically, we used participatory resource mapping exercises in which community members were asked to mark out the areas of collection of both commercial and noncommercial forest produce. Subsequent reconnaissance surveys helped to ground truth the information. Based on this information, we identified eight sites where $C$. strictum was present (Fig.1). These sites were located in three regions in the western part of the NBR: the Nilambur area of Malappuram district in Kerala state, and the southeastern side of the NBR in the Kotagiri and Coonoor regions of the Nilgiris district of Tamil Nadu state. The Nilambur area has an elevation of about $80 \mathrm{~m}$ rising to $2000 \mathrm{~m}$, and an annual rainfall of $2500-5000 \mathrm{~mm}$. The vegetation 
Fig. 1. Location of study sites in the Nilgiri Biosphere Reserve.

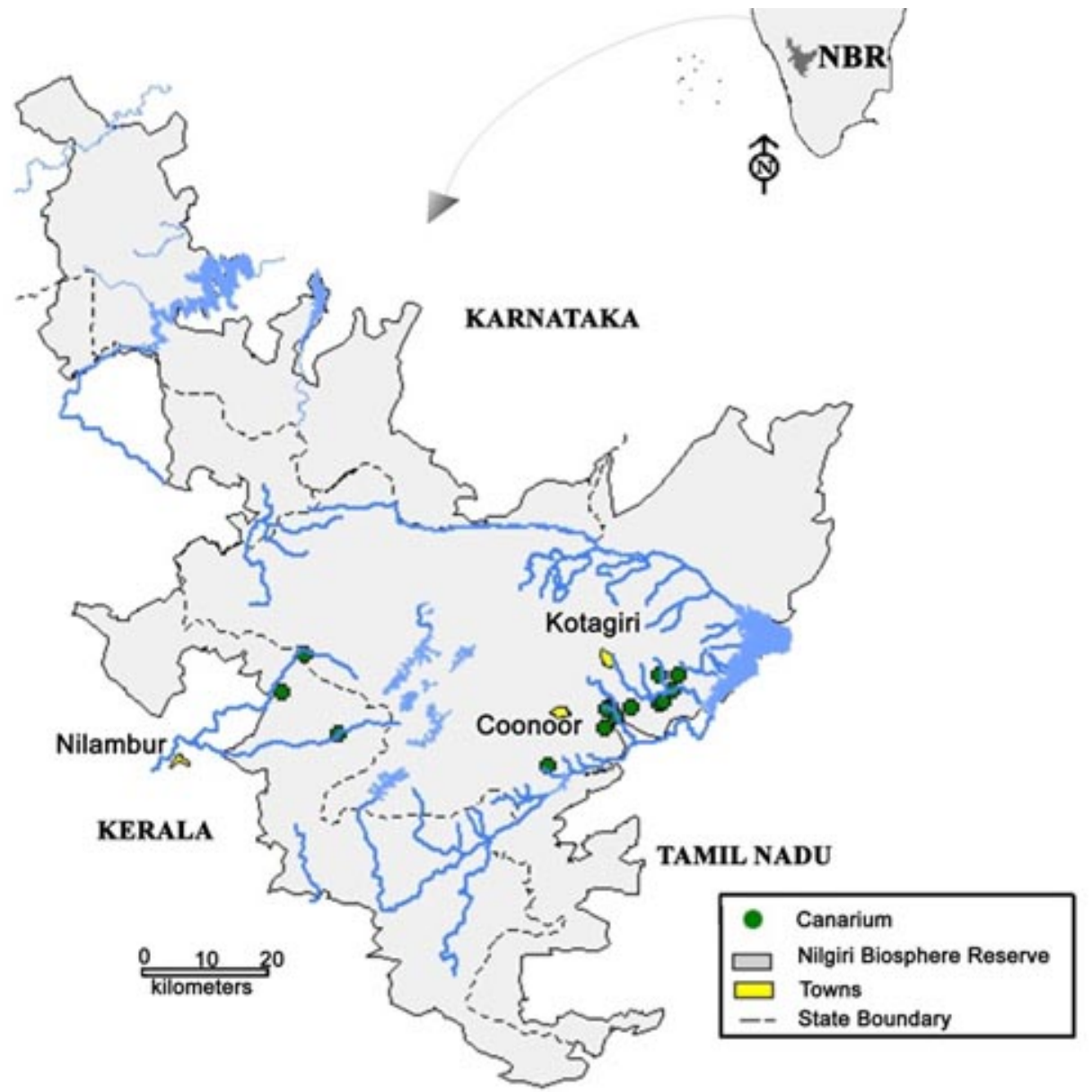

is moist deciduous to dense evergreen forest. The Kotagiri and Coonoor areas lie in the NBR's rainshadow area and harbor dry deciduous and riparian forests. The average rainfall is $1000 \mathrm{~mm}$ for this region and the elevation ranges from $500 \mathrm{~m}$ to 2000 m.

\section{Identification of $C$. strictum Tapping Practices and Trade Routes}

To identify $C$. strictum tapping practices, we carried out focus group interviews in the eight adivasi villages where $C$. strictum harvest occurs (Table 1 ). Focus groups ranged from 3-10 participants, including harvesters and community members, and involved mostly but not exclusively men, because they usually do the resin harvesting. A series of 14 questions were asked, including those related to $C$. strictum management (e.g., How do you select individuals to tap? When is the best time to tap? What are the best ways to tap and why? Which trees do you have the right to tap? Do other animals also use $C$. strictum?) and those related to perceptions on trends in $C$. strictum trade and abundance (e.g., Have $C$. strictum populations fluctuated over time and why? How much do prices fluctuate? Who else harvests this resource?). We also spoke informally with many members in communities across the NBR about their use and knowledge of $C$. strictum. 
To document local demand for and sale of $C$. strictum resin, we interviewed harvesters, local buyers, and dealers at state markets. The only local buyers were the Bagada people, and we carried out interviews in four Badaga villages: Sakatha, Konavakarai, Kengarai, and Kengarai-Kilhatti. In each village, we carried out focus group discussions (4-12 people per group) including women and men, as well as household interviews in 10 homes. A series of 11 questions were asked relating to trends in sale (what kind of $C$. strictum is bought, when, how often) and local perceptions of $C$. strictum availability (e.g., Are you able to purchase what you need? How much did you purchase 10 years ago and what were the rates then?).

We also carried out semi-structured interviews with the four $C$. strictum resin dealers encountered at Virudhhanagar market, one of the largest and most important markets for medicinal plants in South India. We asked each of them ten questions that related to the volume of $C$. strictum traded, place of origin of products, product quality, and buyers and size (national or international) of the market. Focus group discussions and interviews with harvesters and traders took place in Tamil in Tamil Nadu and Malayalam in Kerala.

\section{Assessing Impact of Tapping on $C$. strictum Trees and Populations}

Canarium strictum naturally occurs at low densities and is sparsely distributed (Tambat et al. 2005, Mathachen et al. 2005), with individuals growing clumped together in small patches. Therefore, to assess the impacts of harvest on $C$. strictum population structure, we located the known $C$. strictum patches within the eight study sites with the help of harvesters and local villager members. At each patch, we randomly established one $20 \mathrm{x}$ $20 \mathrm{~m}$ permanent plot, for a total of 22 plots (Table $1)$. In each plot, all $C$. strictum individuals were counted and diameter at breast height (dbh), height, evidence of resin harvest, and flowering/fruiting status were recorded. In addition, the number of incisions per tree, size of the incision (including length, width, and depth of incision), presence or absence of pest attack, and estimated percentage of bark recovery were also recorded for each tree. Harvesters were asked what the method of tapping was at the plots, which was also confirmed during the focus group discussions.

\section{Statistical Analyses}

To assess trends in population structure and density among tapping strategies, we combined the data from the $20 \times 20 \mathrm{~m}$ plots at each site, and considered each site as an independent replicate. We used loglinear analyses to test whether size-class structure was independent of tapping strategy as well as to test if the size-class distribution of incisions was independent of tapping strategy. The Kruskal-Wallis non-parametric test was used to compare differences in $C$. strictum densities across tapping strategies. The overall frequencies (summed across all trees) of resin-yielding trees, termite-attacked incisions, and incisions without signs of recovery were compared between different tapping strategies using Chi Square tests.

\section{RESULTS}

\section{C. strictum Resin-Collection Practices}

Collection of $C$. strictum resin is an ancient activity in the NBR, where several indigenous groups have been harvesting resin for prayer rituals and medicinal purposes since time immemorial. Those engaging in $C$. strictum harvest today are mainly the Cholanaikens and Kattunaikens in Nilambur region and the Kurumbas and the Irulas in the Coonoor area (Table 2).

We documented three main types of resin collection in the NBR, each practiced within a different region. The first type involves the collection of resin formed naturally through fissures on the tree (Fig. 2). This is practiced by communities of the Coonoor slopes (Table 2). Harvesters wait for the C. strictum trees to fissure naturally and then chip the resin protruding from large trees. Typically, there are two or three individuals in a village who go out regularly for the resin and they are the source for the rest of the village.

The second type of resin collection involves making incisions to promote resin flow. This method is largely employed by harvesters in the Kotagiri region (Fig. 3). Harvesters make incisions with curved iron knives and then collect the resin that exudes from the incisions. Once an incision has been tapped, harvesters make new incisions above the previous ones. Tapping intensity is often high, with harvesters making incisions more than $2 \mathrm{~m}$ up the tree trunk, and tying ladders to reach the resin. 
Table 1. Location and characteristics of $C$. strictum study plots in the Nilgiri Biosphere Reserve.

\begin{tabular}{llclccl}
\hline \hline State & Location & Elevation & Forest Type & Precipitation & $\begin{array}{l}\text { No. of } \\
\text { plots }\end{array}$ & Harvest method \\
\hline Tamil Nadu & Kavalkombei & $1196 \mathrm{~m}$ & Evergreen & $1000 \mathrm{~mm}$ & 2 & Natural fissures \\
Tamil Nadu & Pudurcombei & $897 \mathrm{~m}$ & Evergreen & $1000 \mathrm{~mm}$ & 3 & Natural fissures \\
Tamil Nadu & Deepdale & $1400 \mathrm{~m}$ & Evergreen & & 2 & Incision \\
Tamil Nadu & Seminarai & $900-1100 \mathrm{~m}$ & Semi evergreen & $800 \mathrm{~mm}$ & 3 & Incision \\
Tamil Nadu & Melcoop & $1100 \mathrm{~m}$ & Semi-evergreen & $800 \mathrm{~mm}$ & 2 & Incision \\
Tamil Nadu & Maricode & $\sim 900 \mathrm{~m}$ & Semi-evergreen & $1000 \mathrm{~mm}$ & 2 & Incision \\
Kerala & Panapuzha & $516 \mathrm{~m}$ & Evergreen & $2000 \mathrm{~mm}$ & 3 & Fire and incision \\
Kerala & Alakal & $200-600 \mathrm{~m}$ & Semi-evergreen & $2000 \mathrm{~mm}$ & 6 & Fire and incision \\
\hline
\end{tabular}

Harvesters reported that trees could be tapped once they reached about $100 \mathrm{~cm}$ girth at breast height (gbh). Resin tapping in this region was a traditional activity of the Kurumbas alone, but now some Irulas are also involved.

The third type of resin-collection strategy involves setting a low fire followed by incisions and resin collection (Fig. 4). This method is used by harvesters in Nilambur region (Kerala state). To promote the flow of resin, a low fire is lit at the base of the tree once it has been judged to be a resinyielding tree. The harvesters said they are able to make this judgment by looking at the thickness of the bark and by tapping it to check. Harvesters of Alakal village mentioned that they were able to tell also by looking at the leaves, as resin-yielding trees have smaller leaves than trees that do not yield resin. The fire is lit on the east side of the tree, and then incisions are carefully made along the same side of the tree and spread across up to $50 \%$ of the trunk circumference. Harvesters said this is to ensure the stability of the tree. After the fire is lit and incisions made, harvesters return after some time (see below) to collect the resin. Harvesters reported that resin can be harvested regularly for 3-4 years by making fresh incisions at every visit. Harvesters said that trees could be tapped once they reached $50 \mathrm{~cm}$ gbh. The Cholanaikens were the first of the resin collectors in the Nilambur, and they mention that the Paniyas have begun to harvest only recently.

\section{Variation in Collection Rates, Tenure Regimes, and Resin Quality}

Our interviews revealed that there was high variation both within and across the three general collection practices, especially in terms of timing and frequency of collection, tenure regimes, and quality of resin harvested (Table 2).

Generally, harvesters in Kotagiri and Coonoor, all of whom used natural fissures or incisions without fire to extract resin, collect all year round except during the monsoons. They said that the resin does not harden during the rainy period. The harvesters of Maancheery in Kerala, who use fire to harvest, also reported that it is not viable to harvest the resin in the rains. In contrast, all the other harvesters who use fire to harvest reported that they harvest only during the monsoon. Indeed, the harvesters of Alakal village maintained that it is a proof of one's identity as a true Naikan that you only harvest resin during the monsoon. These differences in timing of resin tapping across villages could be in part a result of differential access to forests: Tamil Nadu forests 
Table 2. Types and patterns of $C$. strictum resin harvest in indigenous villages of the Nilgiri Biosphere Reserve.

\begin{tabular}{|c|c|c|c|c|c|c|c|c|c|c|c|}
\hline \multirow[t]{2}{*}{ State } & \multirow[t]{2}{*}{ Village } & \multirow{2}{*}{$\begin{array}{l}\text { Name of } \\
\text { Indigenous } \\
\text { Group(s) }\end{array}$} & \multirow[t]{2}{*}{$\begin{array}{l}\text { Harvest } \\
\text { Method }\end{array}$} & \multirow{2}{*}{$\begin{array}{l}\text { Tenure } \\
\text { system } \\
\text { observed } \\
\text { for } C \text {. } \\
\text { strictum }\end{array}$} & \multirow{2}{*}{$\begin{array}{l}\text { Rate of } \\
\text { harvest }^{2}\end{array}$} & \multirow[t]{2}{*}{$\begin{array}{l}\text { Season for } \\
\text { harvest }\end{array}$} & \multirow{2}{*}{$\begin{array}{l}\text { Starting } \\
\text { tree size } \\
\text { for har- } \\
\text { vest (G- } \\
\text { BH) }\end{array}$} & \multirow{2}{*}{$\begin{array}{l}\text { Yield of } \\
\text { resin per } \\
\text { tree tapped }\end{array}$} & \multicolumn{3}{|c|}{$\begin{array}{l}\text { Grade of resin } \\
\text { harvested }(Y=\text { yes })\end{array}$} \\
\hline & & & & & & & & & 1 & 2 & 3 \\
\hline Kerala & Maancheery & Cholanaikan & $\begin{array}{l}\text { Fire \& } \\
\text { incisions; } \\
\text { wait } 2 \\
\text { wk }\end{array}$ & $\mathrm{N}$ & $\begin{array}{l}3 \mathrm{~d} / \mathrm{wk} \\
10 \mathrm{x} / \mathrm{yr}\end{array}$ & $\begin{array}{l}\text { Not during } \\
\text { monsoon }\end{array}$ & $50 \mathrm{~cm}$ & $\begin{array}{l}0.5 \mathrm{~kg} / \\
\text { tree }\end{array}$ & $\begin{array}{l}\text { (until } \\
5 \text { yrs } \\
\text { ago) }\end{array}$ & $\mathrm{Y}$ & $\mathrm{Y}$ \\
\hline Kerala & Alakal & Cholanaikan & $\begin{array}{l}\text { Fire \& } \\
\text { incisions; } \\
\text { wait } 3 \\
\text { mos }\end{array}$ & $\mathrm{Y}$ & $\begin{array}{l}15 \mathrm{~kg} / \\
\text { day }(2- \\
3 x \text { per } \\
\text { monsoon })\end{array}$ & $\begin{array}{l}\text { Monsoon } \\
\text { only }\end{array}$ & $50 \mathrm{~cm}$ & $5 \mathrm{~kg} /$ tree & & $\mathrm{Y}$ & \\
\hline Kerala & Appankaapu & Kaatunaikan & $\begin{array}{l}\text { Fire \& } \\
\text { incisions } \\
\text { wait } 1 \mathrm{yr}\end{array}$ & $\mathrm{Y}$ & $\begin{array}{l}2 \mathrm{x} \text { per } \\
\text { monsoon }\end{array}$ & $\begin{array}{l}\text { Monsoon; } \\
\text { set during } \\
\text { honey h- } \\
\text { unting }\end{array}$ & $50 \mathrm{~cm}$ & $\begin{array}{l}1-5 \mathrm{~kg} / \\
\text { tree. Up } \\
\text { to } 10\end{array}$ & $\mathrm{Y}$ & $\mathrm{Y}$ & \\
\hline Kerala & Thandankallu & Paniyas & $\begin{array}{l}\text { Fire \& } \\
\text { incisions }\end{array}$ & $\mathrm{N}$ & $\begin{array}{l}2 \mathrm{x} \text { per } \\
\text { monsoon }\end{array}$ & Monsoon & $50 \mathrm{~cm}$ & $\begin{array}{l}1-5 \mathrm{~kg} / \\
\text { tree }\end{array}$ & & & Y \\
\hline $\begin{array}{l}\text { Tamil } \\
\text { Nadu }\end{array}$ & Dhalamukh & Irula/Kurumba & $\begin{array}{l}\text { Incisions } \\
\text { only }\end{array}$ & $\begin{array}{l}\text { Y (villa- } \\
\text { ge })^{1}\end{array}$ & $2-3 \mathrm{~kg} / \mathrm{wk}$ & Y Year round & $100 \mathrm{~cm}$ & NA & & & $\mathrm{Y}$ \\
\hline $\begin{array}{l}\text { Tamil } \\
\text { Nadu }\end{array}$ & Semenarai & Irula/Kurumba & $\begin{array}{l}\text { Incisions } \\
\text { only }\end{array}$ & $\begin{array}{l}\text { Y (Vill- } \\
\text { age) }\end{array}$ & 3-4 kg/wk & x $1 / \mathrm{mo}$ & $100 \mathrm{~cm}$ & NA & & $\mathrm{Y}$ & $\mathrm{Y}$ \\
\hline $\begin{array}{l}\text { Tamil } \\
\text { Nadu }\end{array}$ & Kavalkombei & Kurumba & $\begin{array}{l}\text { Natural } \\
\text { fissures }\end{array}$ & $\begin{array}{l}\text { Y (villa- } \\
\text { ge) }\end{array}$ & $5 \mathrm{~kg} / \mathrm{wk}$ & Year round & $100 \mathrm{~cm}$ & $1 \mathrm{~kg}$ & $\mathrm{Y}$ & $\mathrm{Y}$ & \\
\hline $\begin{array}{l}\text { Tamil } \\
\text { Nadu }\end{array}$ & Marikode & Kurumba & $\begin{array}{l}\text { Incisions } \\
\text { and natural } \\
\text { fissures }\end{array}$ & $\begin{array}{l}\text { Y (Vill- } \\
\text { age) }\end{array}$ & $\begin{array}{l}1.5 \mathrm{~kg} / \mathrm{wk} ; \\
5-6 \mathrm{~kg} / \\
\text { mo }\end{array}$ & Jan-Apr & $100 \mathrm{~cm}$ & NA & $\mathrm{Y}$ & $\mathrm{Y}$ & \\
\hline
\end{tabular}

${ }^{1}$ Tenure is respected at the level of the villages, but not areas within villages (see text)

${ }^{2}$ Units of measurement are not consistent across communities as some discussed harvest rates in terms of $\mathrm{kg}$ and other in terms of frequency.

are closed to NTFP harvest during the monsoon, but this is not the case in Kerala. In addition, in contrast to the other Kerala villages in this study, the geographic location of Maancheery makes access to their forests very difficult during the monsoon.

Tenure regimes over $C$. strictum trees and harvest frequency varied from village to village as well (Table 2) and have been changing over time. For example, for those communities that use fire to tap resin, both the Cholanaikens of Alakal and the Kattunaikens of Appankaapu follow strict rules for $C$. strictum tenure and do not trespass into another person's forest area for harvest. Each person has the sole right to harvest resin from the trees within their designated area. The Kattunaikens harvest the resin only one full year after "preparing" the trees (setting fire and making incisions), whereas the 
Fig. 2. Figs. 2-4. Three resin collection practices carried out in the Nilgiri Biosphere Reserve. (2) Resin harvest from natural fissures.

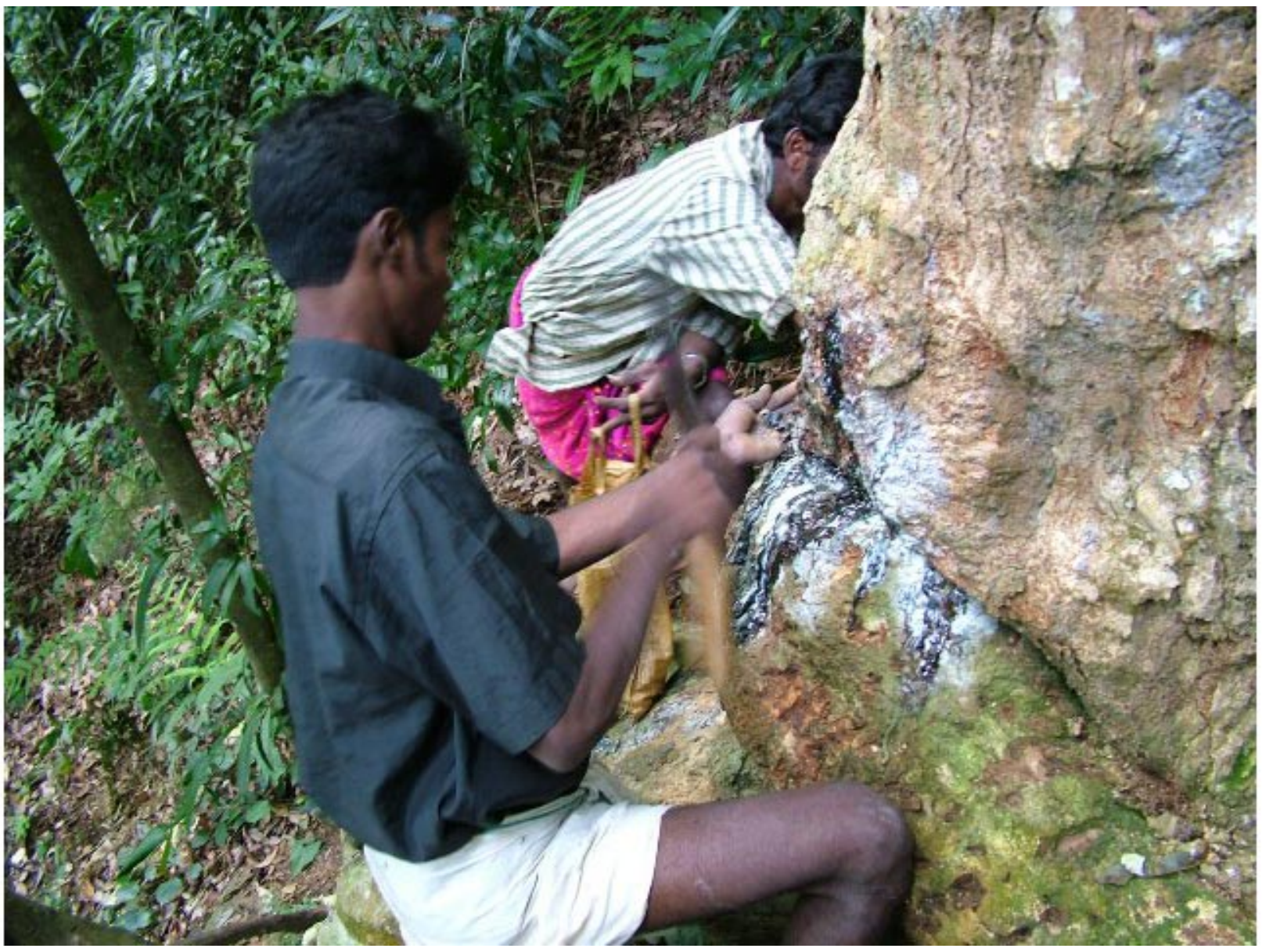

Cholanaikens of Alakal harvest the resin after 3 months. They go to harvest as a family and very often the women are involved in the preparation of the tree. The Cholanaikens of Maancheery said that in the past they used to wait 1 year between preparing the tree and harvesting the resin, but that this was when strict tenure was observed. They reported that as of about 5 years ago the young people no longer respect the boundaries of the elders, and that whoever passes by a $C$. strictum tree will take the resin, no matter whose tree it is. With breakdown of tenure, the fire periods are shorter and resin is now harvested within 2 weeks after preparing the tree. The Paniya harvesters of Thandankallu follow no rules of tenure.
In the Coonoor and Kotagiri regions, tenure patterns have changed as well and now $C$. strictum harvesters have very broad $C$. strictum tenure regimes. A region is marked for a village and that boundary is held in respect by harvesters. However, within the village the respect for each other's rights to tenure over specific trees has vanished and anyone passing by can pick up the resin if they see it. In the Kotagiri area, there have also been changes in the rituals carried out during resin harvest and in who was traditionally permitted to harvest resin. For example, the Kurumbas related that in the past it was only the priest - after keeping himself ritually clean for a period of time-who started the resin harvest rituals, and only he was allowed to harvest the resin. However, this is no longer the case today. 
Fig. 3. Resin harvest using incisions.

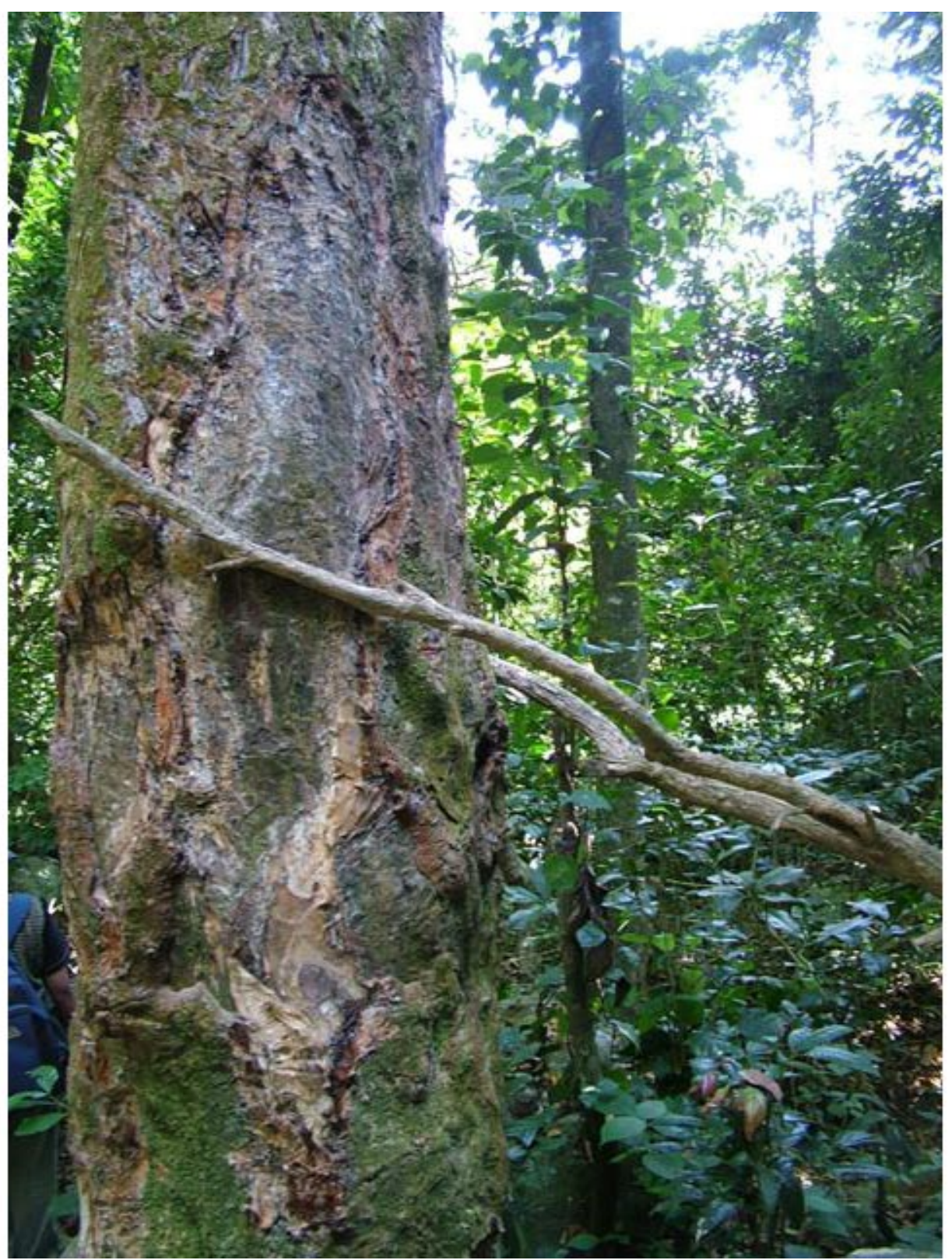

The grades of resin produced by the different villages varied greatly (Table 3 ). The quality of resin traded is classified into three types (Figs 5-7, Table 4). Grade 1 consists of the largest pieces of resin, about 30-60 cm long, and Grade 2 resin consists of smaller pieces, about $5-7.5 \mathrm{~cm}$ long. The size of the resin obtained depends on how long it is left to accumulate on the tree before harvest. Grade 3 is a powdered form of the resin and is obtained when small amounts of resin are scraped off the tree only a day or two after incisions are made. It usually inludes pieces of bark as well.

Local livelihood strategies and pressures on forest areas were also variable across villages and regions (Table 4). Villages had different levels of 
Fig. 4. Resin harvest using fire and incisions.

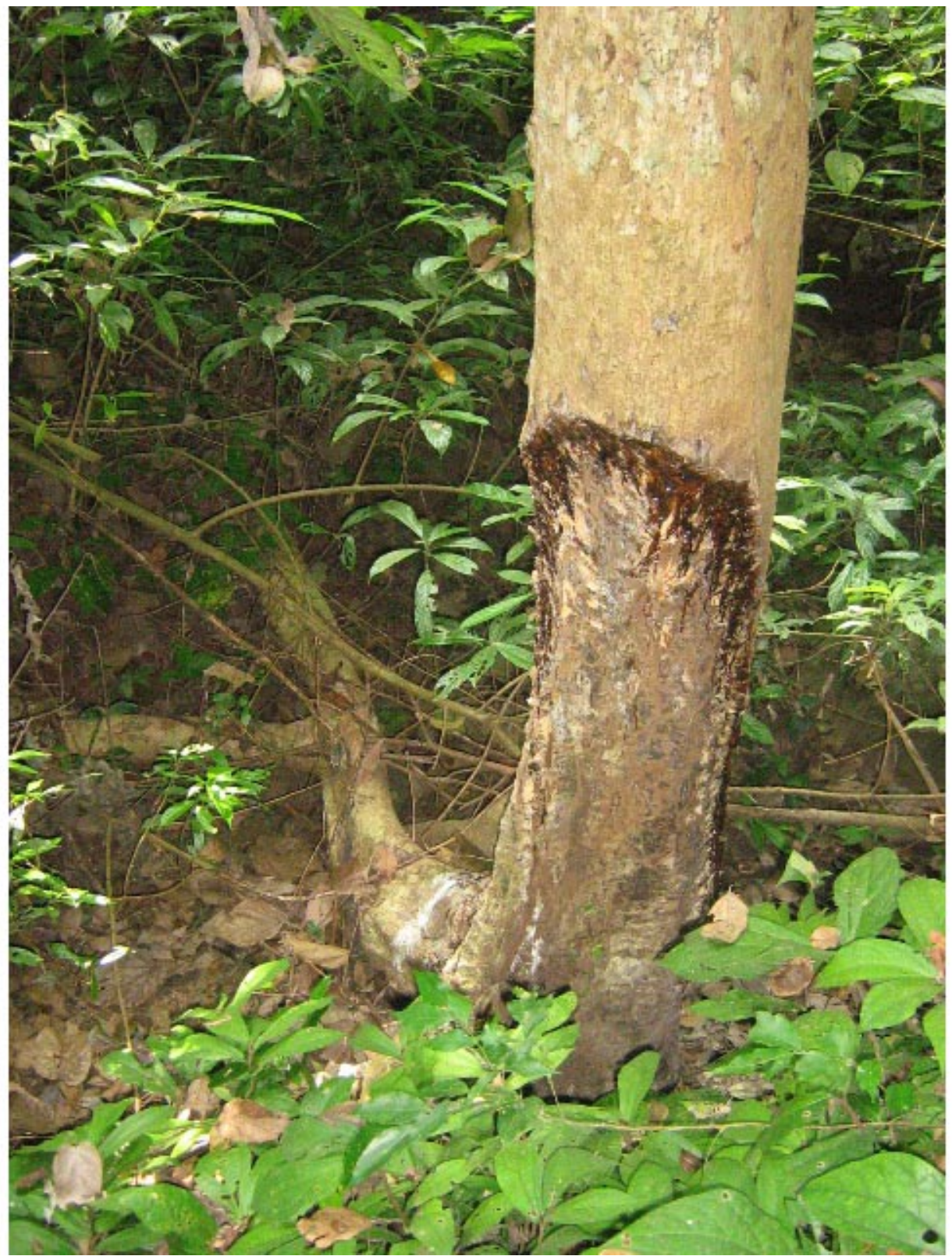

dependency on forest products, subsistence farming, and wage labor. Pressures on forests and C. strictum resources included illegal harvest by outside harvesters, high populations of local harvesters, and the expansion of tea estates into Reserve Forest lands.

\section{C. strictum Resin Trade Routes}

Canarium strictum is harvested for local use in prayer rituals by adivasi communities in the NBR as well as for trade both within and outside the NBR (Table 5). In the Kotagiri area, the resin for trade is sold within the NBR only, as high demand comes 
Table 3. Characteristics and prices of different grades of $C$. strictum resin. Rs $=$ Indian Rupees.

\begin{tabular}{|c|c|c|c|c|c|}
\hline \multirow[t]{2}{*}{ Grade } & \multirow[t]{2}{*}{ Size } & \multirow[t]{2}{*}{ Color } & \multicolumn{3}{|c|}{ Price } \\
\hline & & & $\begin{array}{l}\text { Alakal } \\
\text { (Nilambur) }\end{array}$ & $\begin{array}{l}\text { Dhalamukh } \\
\text { (Kotagiri) }\end{array}$ & $\begin{array}{l}\text { Kavalk-ombei (Co- } \\
\text { noor) }\end{array}$ \\
\hline 1 & $30-60 \mathrm{~cm}$ & Glassy brownish-black & Rs 25 & Rs 50 & Rs 70 \\
\hline 2 & $5-7.5 \mathrm{~cm}$ & $\begin{array}{l}\text { Glassy translucent } \\
\text { brown }\end{array}$ & Rs 25 & Rs 40 & Rs 40 \\
\hline 3 & Powder & Grayish & Rs 12 & Rs 30 & \\
\hline
\end{tabular}

from local Badaga villages, The Badaga, an ethnic group of the Nilgiri plateau, are agriculturalists and hold high reverence for $C$. strictum resin, but they do not have access to it as it does not grow at the elevation where they live. In the words of one of the Badaga elders we interviewed in the village of Kengarai, "The Kurumbas are our brothers and if they do not bring the dhupa (local name for $C$. strictum resin) for our gods, we will be stranded."

The Badaga burn the resin as incense for prayers, and is also a must in the annual temple festivals. Our interviews revealed that on average each house keeps a stock of resin and uses between 2-3 kgs of resin a year for their home needs. The quality of the resin we were shown in five of the eight houses we visited was Grade 2, with the remaining houses using Grade 3 resin. The Badagas reported that Grade 2 resin is priced between $50-80$ rupees $/ \mathrm{kg}$ today, but that 2 years ago it cost 30 rupees $/ \mathrm{kg}$. In addition, although in the past resin was supplied by the Kurumbas, today many Irulas are also bringing the resin to the Bagada.

In contrast to Kotagiri region described above, the resin that is sold from the Coonoor and Nilambur regions is sold to industry outside the NBR. However, the trade routes are very different in Conoor and Nilambur (Table 5). In Coonoor (Tamil Nadu state), where commercial resin harvest is illegal, resin is generally sold by the gatherers to local contractors, who then sell to larger contractors, who in turn sell to regional herbal plant markets in Tamil Nadu state. The $C$. strictum vendors we interviewed at the Virudhhanagar market, one of the largest market herbal markets in South India, told us how gatherers used to bring the resin in head loads like firewood. One vendor who had been in the business for 50 years had a $1.2 \mathrm{~m}$ long piece of resin hanging from the wall, testimony to a bygone era. The vendors reported that about $70 \%$ of their produce goes to the paint and varnish industry and the rest to the incense makers. They said that they do not get much resin from Tamil Nadu now and buy mostly from Kerala. At this market $C$. strictum resin was sold in five grades, as opposed to the three recognized within the NBR.

In Nilambur (Kerala state), where commercial resin harvest is legal, the resin extracted by harvesters is traded at the local Minor Forest Produce Society (MFPS), which has local trade depots at each of the resin-harvesting villages as well as a centralized office in Nilambur town (Table 6). The resin is stored in large gunny sacks and is sorted at the Society. It is then sold through a system of auctions from the MFPS central office at Thrissur. The buyers are from Tamil Nadu, who then sell to the paint and varnish industries. According to the 2005 figures from the MFPS central office, $200 \mathrm{~kg}$ of Grade 1 resin was collected, 8 tons of Grade 2, and 3 tons of Grade 3 resin. The records indicate that Maacheery and Alakal were the highest producers of $C$. strictum resin and that it was sold mostly during the monsoon period.

The price that harvesters receive for the different qualities of resin shows much variation across regions (Table 3). Rates were lowest in Kerala, where harvest is legal and there is no difference in price between Grades 1 and 2 resin. The price of Grade 1 resin was almost three times as high in Coonoor as in Nilambur. 
Fig. 5. Figs. 5-7. Different grades of C. strictum resin quality sold in South India. (5) Grade 1.

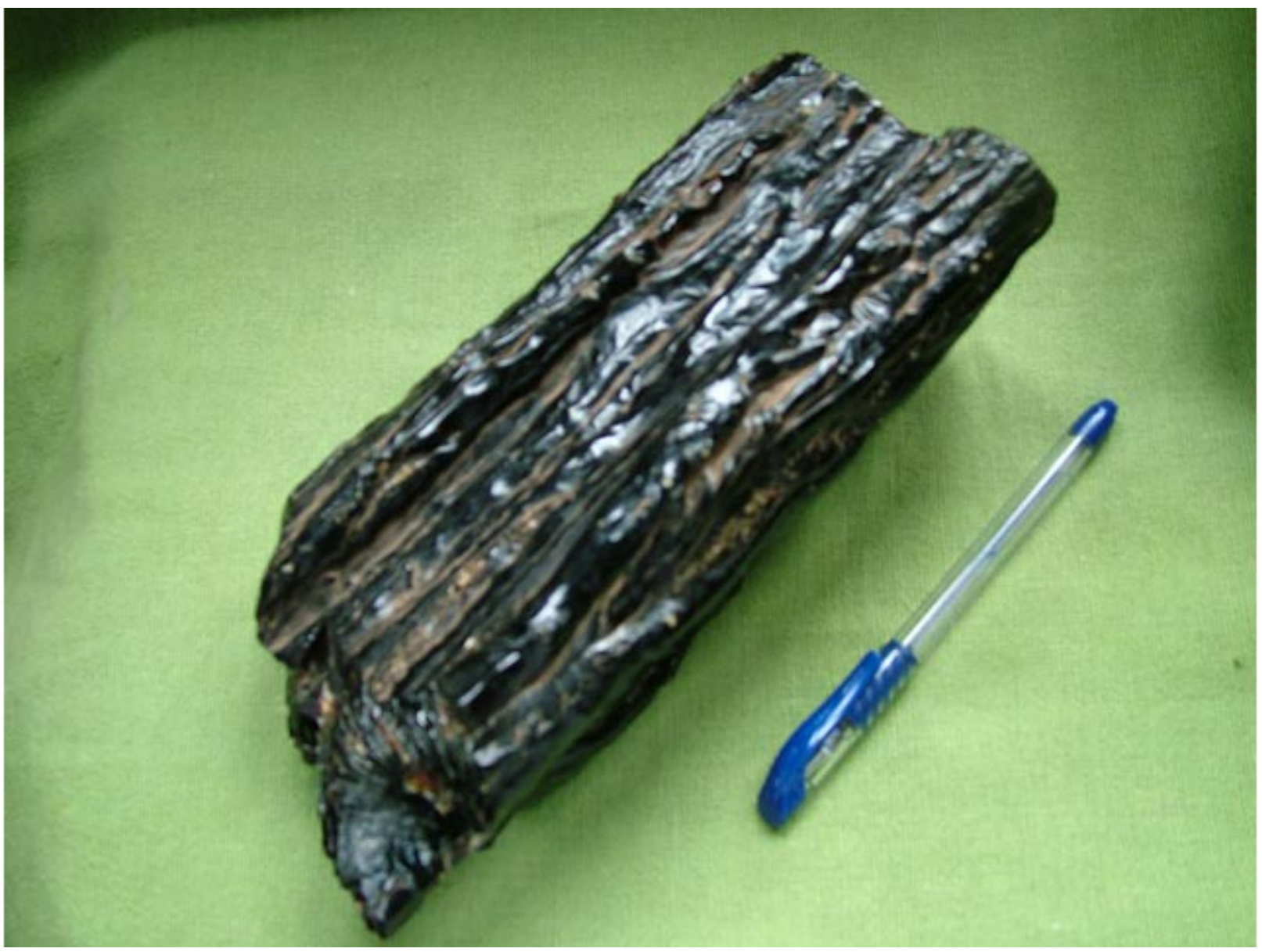

\section{Local Knowledge and Perceptions of Change in C. strictum Populations over Time}

Across the villages in the NBR, there was a common perception that $C$. strictum populations have been decreasing over the years and that, in particular, the number of large trees is decreasing. The harvesters in Nilambur region, where fire is used in tapping, all commented that a tree survives for only 3 to 4 years after they start the tapping process. In Kotagiri region, people commented that today the large trees fall easily with the wind. The one exception to this perception was the village of Alakal, Kerala, where the harvesters felt that $C$. strictum was still found over a large area.
The harvesters of Kotagiri and Coonoor commented that not all trees produce resin, and distinguished between "male" and "female" trees, with all resinyielding trees being female. The harvesters did comment on any seasonal variations in resin production and, as described above, most harvest year round. Harvesters mentioned that $C$. strictum fruits are eaten and dispersed by pigeons, and also commented that they have seen civets and giant squirrels feed on the fruit and that the endemic Nilgiri langurs (Semnopithecus johnii) eat the young flush of $C$. strictum leaves. Most of them also mentioned that the dammar bee (Trigona spp.) takes the resin for building its home, as well as another unidentified stinging insect. 
Fig. 6. Grade 2 resin.

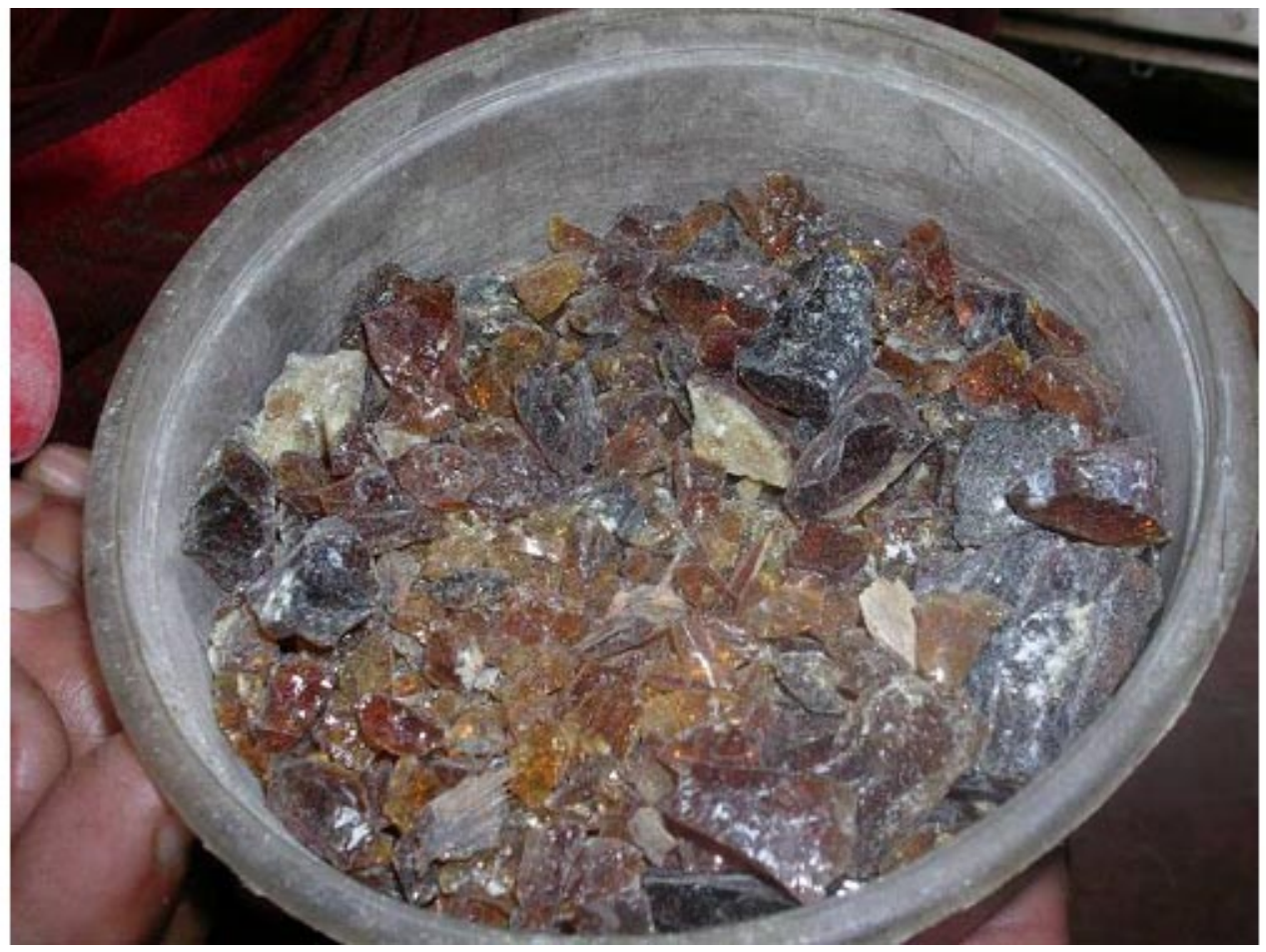

\section{Impact of Resin Tapping on C. strictum Individuals and Populations}

A total of $154 C$. strictum individuals were found in the 22 plots in the eight study locations. Of these locations, two were subject to resin harvest from natural fissures (37 individuals), four to tapping using incisions (97 individuals), and two to fire combined with incisions (20 individuals) (Table 1).

The structure of $C$. strictum populations was variable both within and across collection strategies (Fig. 8). However, there was a clear lack of large individuals in populations subject to tapping by incisions, and incisions and fire. Populations that were subject to both fire and incisions were dominated by the smaller size classes and had no individuals that were $>60 \mathrm{~cm}$ dbh. Populations subject to incisions showed a reverse-J curve, with a greater number of individuals in the smaller size classes and a steeper decrease in the number of individuals with increasing size class. These populations had no individuals $>91 \mathrm{~cm} \mathrm{dbh}$. Only populations subject to harvest by natural fissures had individuals in the largest size class $(>100 \mathrm{~cm}$ $\mathrm{dbh}$ ). These populations showed a small and gradual decrease in number of individuals with increasing size class, and $20 \%$ of individuals were $>100 \mathrm{~cm}$ $\mathrm{dbh}$. Loglinear analyses revealed that number of individuals per size class was dependent on collection strategy $\left(\mathrm{df}=6, \chi^{2}=206.42, p<0.001\right.$, Fig. 8). However, this was driven by a significant difference in the largest size class only (KrukalWallis df $=2, \chi^{2}=7, p=0.03$ ). Overall, the two sites subject to fire had lower densities than the six sites that were not subject to fire $\left(\mathrm{df}=1, \chi^{2}=2, p\right.$ $=0.045$ ).

Populations subject to fire and incisions had a greater proportion of the smaller trees that were harvested (Table 7). When considering all individuals $>10 \mathrm{~cm}$ dbh, $61.5 \%$ of the trees in populations subject to fire and incisions were resin yielding as opposed to $39 \%$ of trees in populations tapped using incisions only. However, this difference was not significant. Trees below about 
Fig. 7. Grade 3 resin.

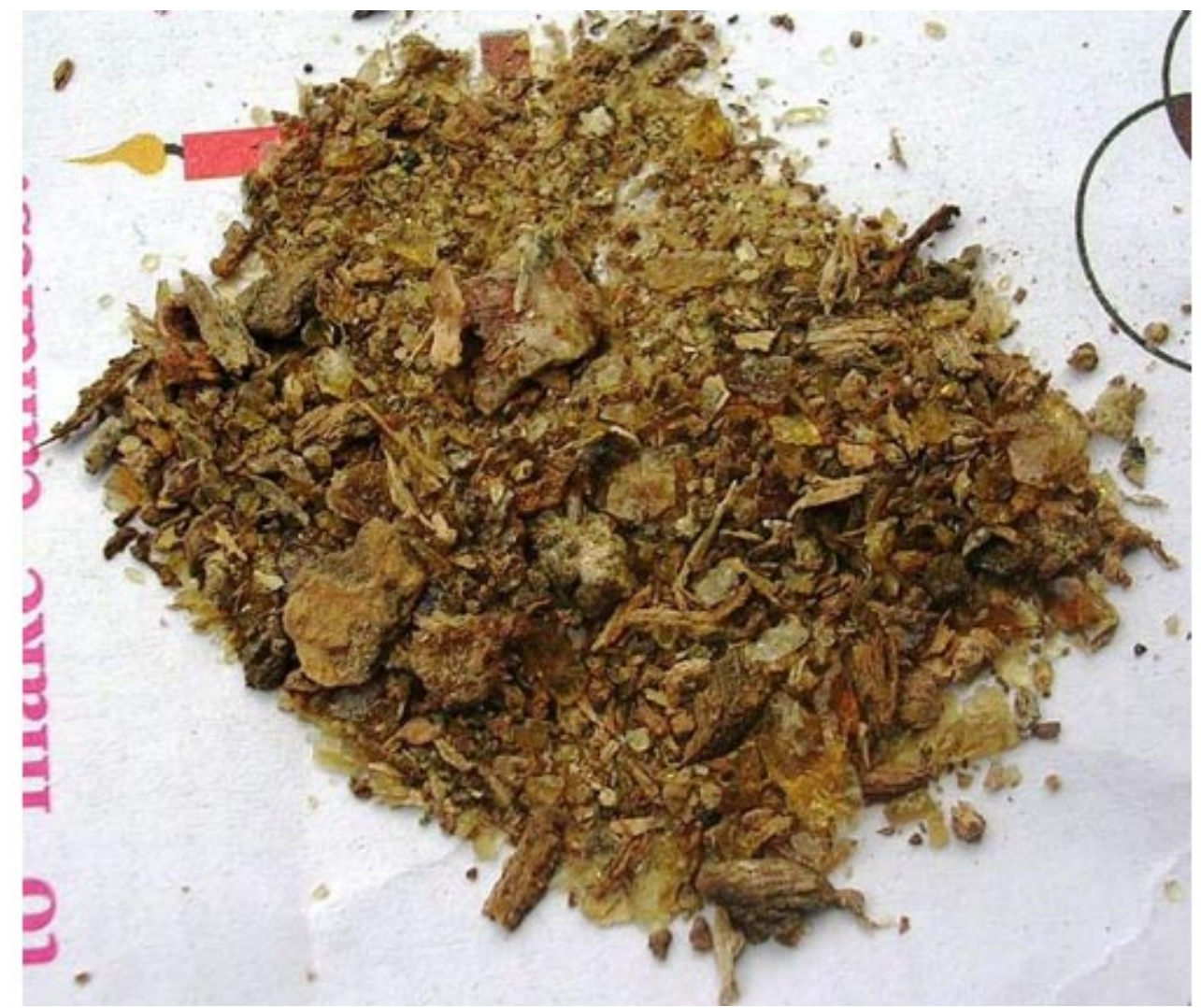

$10 \mathrm{~cm}$ dbh were generally not harvested for their resin in any of the populations, although there were a few exceptions.

There were significant differences between the two tapping strategies with respect to recovery after incisions and termite attack (Table 7). Eighteen percent of the trees subject to fire and incision showed signs of termite attack whereas this figure was $11 \%$ for trees tapped using incisions only. In addition, in populations subject to incisions and fire, termite attacks were seen on trees with dbh as low as of $7 \mathrm{~cm}$ whereas in populations subject to tapping without fire, the termite attacks were observed on trees with a minimum dbh of $27 \mathrm{~cm}$. There were no signs of termite attack on any of the trees in populations where resin is collected from natural fissures.

In terms of recovery from incision, $80 \%$ of the incisions on trees subject to fire and incision showed no sign of recovery at all, whereas this figure was $59 \%$ for trees tapped using incision only and this difference was significant (Table 7). We considered incisions to be recovering when bark was observed re-growing over the cut. When considering only those trees that had incisions, the number of incisions per tree increased significantly with tree size $(\mathrm{dbh})(r=0.13, p<0.02)$. The range of variation in incisions sizes was similar for both harvest strategies: incision lengths ranged up to $175 \mathrm{~cm}$ long, incision widths up to $50 \mathrm{~cm}$ wide, and incision depths up to $6 \mathrm{~cm}$ deep. However, in populations where fire was used, a significantly greater proportion of incisions were found in the larger size classes $\left(n=281\right.$, df $=1, \chi^{2}=14.4, p=0.006$, Fig. $9)$. In our observations, only one incision was being actively tapped per tree. For both tapping strategies, we observed that the rate of recovery is higher with smaller incisions, but we were unable to test this statistically as we did not know the exact age of all incisions. 
Table 4. Variation in livelihood strategies and pressures on $C$. strictum populations and habitat across villages in the Nilgiri Biosphere Reserve.

\begin{tabular}{|c|c|c|c|}
\hline State & Village & Livelihood Strategies & $\begin{array}{l}\text { Pressures on } C \text {. strictum populations and } \\
\text { habitat }\end{array}$ \\
\hline Kerala & Maancheery & $\begin{array}{l}\text { Collection of forest } \\
\text { products }\end{array}$ & $\begin{array}{l}\text { Low human populations but harvesters from } \\
\text { other villages come to harvest, therefore } \\
\text { tenure system breaking down }\end{array}$ \\
\hline Kerala & Alakal & $\begin{array}{l}\text { Wage labor \& collection } \\
\text { of forest products }\end{array}$ & $\begin{array}{l}\text { Medium pressure, many harvesters and local } \\
\text { traders close by }\end{array}$ \\
\hline Kerala & Appankaapu & $\begin{array}{l}\text { Wage labor \& collection } \\
\text { of forest products }\end{array}$ & High pressure with many harvesters \\
\hline Kerala & Thandankallu & $\begin{array}{l}\text { Total dependence on wage } \\
\text { labor }\end{array}$ & $\begin{array}{l}\text { Low pressure-not traditional harvesters of } \\
\text { resin }\end{array}$ \\
\hline Tamil Nadu & Dhalamukh & $\begin{array}{l}\text { Wage labor \& subsistence } \\
\text { agriculture \& collection of } \\
\text { forest products }\end{array}$ & $\begin{array}{l}\text { High pressure: high demand from local } \\
\text { Badaga communities. Habitat loss due to } \\
\text { expansion of tea estates }\end{array}$ \\
\hline Tamil Nadu & Semenarai & $\begin{array}{l}\text { Wage labor \& subsistence } \\
\text { agriculture \& collection of } \\
\text { forest products }\end{array}$ & $\begin{array}{l}\text { High pressure: high demand from local } \\
\text { Badaga communities. Habitat loss due to } \\
\text { expansion of tea estates }\end{array}$ \\
\hline Tamil Nadu & Kavalkombei & $\begin{array}{l}\text { Wage labor \& collection } \\
\text { of forest products }\end{array}$ & $\begin{array}{l}\text { Low pressure-low human populations and } \\
\text { large areas of forest }\end{array}$ \\
\hline Tamil Nadu & Marikode & $\begin{array}{l}\text { Subsistence agriculture \& } \\
\text { wage labor \& collection of } \\
\text { forest products }\end{array}$ & $\begin{array}{l}\text { Low pressure-low human populations and } \\
\text { forest lands converted to tea years ago }\end{array}$ \\
\hline
\end{tabular}

\section{DISCUSSION}

Black dammar, the resin obtained from Canarium strictum, is one of many important NTFP that are used, harvested, and sold by indigenous (adivasi) communities in the NBR (Keystone Foundation 2007) and throughout the Western Ghats (Murali et al. 1996, Muraleedharan et al. 2005), and one of thousands of NTFP on which local populations worldwide depend (Vedeld et al. 2004). Our research illustrates the large variation in collection strategies and trade of $C$. strictum harvest within the NBR, and sheds light on some of the social, ecological, and economic factors that can influence the potential for sustainable harvest of this and other NTFP.

\section{Relationship between Tapping Practices, Tenure, and Resin Quality}

Research on other NTFP has demonstrated that there can be wide variation in harvest and management strategies across communities (Nantel et al. 1996, Ticktin and Johns 2002, Ghirmire et al. 2005). Here, we documented three broad strategies for tapping resin, each found in a different region of the NBR: collection from natural fissures, tapping using incisions, and tapping using fire and incisions. We also found very large variation within each of these three regimes in terms of frequency and timing of tapping.

Our results indicate that it is not differences among the three broad collection strategies, but rather within the collection strategies in terms of frequency and intensity of harvest, that leads to differences in 
Table 5. Local and regional trade routes for C. strictum resin in Tamil Nadu and Kerala states.

\begin{tabular}{|c|c|c|c|c|c|c|c|}
\hline \multirow[t]{2}{*}{ State } & \multirow[t]{2}{*}{ Legality } & \multirow{2}{*}{$\begin{array}{l}\text { Use by } \\
\text { collector com- } \\
\text { munities }\end{array}$} & \multicolumn{2}{|c|}{ Local Trade } & \multicolumn{3}{|c|}{ Regional Trade } \\
\hline & & & Local buyers & Use & Trade route & $\begin{array}{l}\text { Location of } \\
\text { markets }\end{array}$ & Uses \\
\hline Tamil Nadu & Not Permitted & $\begin{array}{l}\text { Prayer rituals, } \\
\text { medicine }\end{array}$ & $\begin{array}{l}\text { Bagada villa- } \\
\text { ges }\end{array}$ & Prayer rituals & $\begin{array}{l}\text { Sale through } \\
\text { contractors to } \\
\text { buyers in South } \\
\text { Tamil Nadu }\end{array}$ & $\begin{array}{l}\text { South Tamil } \\
\text { Nadu } \\
\text { and Kerala }\end{array}$ & $\begin{array}{l}\text { Incense industry } \\
\text { Paint and } \\
\text { varnish indu- } \\
\text { stry, matchstick } \\
\text { industry }\end{array}$ \\
\hline Kerala & Permitted & $\begin{array}{l}\text { Prayer rituals, } \\
\text { medicine }\end{array}$ & Local people & $\begin{array}{l}\text { Prayer incense } \\
\text { and house } \\
\text { fumigation (to } \\
\text { kill mosquit- } \\
\text { oes) }\end{array}$ & $\begin{array}{l}\text { Auctioned through } \\
\text { the MFP } \\
\text { Federation sale } \\
\text { mostly to } \\
\text { buyers from } \\
\text { Tamil Nadu }\end{array}$ & & \\
\hline
\end{tabular}

the quality of resin harvested-and that these in large part reflect differences in tenure regimes. For example, of those villages that harvest resin using fire and incisions, only the two communities where harvesters have tenure over their trees sold the higher grades of resin (Grades 1 or 2). Similarly, the villages with no tenure systems were selling the lowest grade powder form. In these villages, anyone passing by a resin-yielding tree harvests what is available at the moment. Across all the villages and collection strategies, only those where there was some tenure over $C$. strictum, either at the individual or village level, produced Grade 2 resin. In addition, there were examples of all three harvest strategies producing Grade 1 resin. This included Kavalcombei, where resin is obtained from natural fissures and demand is low, as well as Apankaapu, where demand is high and fire is used, but where tenure rules are strict and harvesters wait one full year between incision making and harvest.

These trends are easily explained because resin quality depends on the size of resin blocks obtained, and larger blocks need much longer periods of time to form, and therefore, necessitate lower harvest frequency. If demand is high, the time periods required for high-grade resin to form can only occur when some kind of tenure is respected.

\section{Social and Economic Factors Influencing Changes in Tenure and Resin Collection Practices}

Secure tenure systems and other local institutions that regulate the use of, and access to, resources are critical components of local management systems, and represent a key to ensuring sustainability (Gadgil et al. 1993, Berkes 1999). In Southeast Asia, Dipterocarp resin harvesters often have ownership over individual trees and these rights are hereditary (Ankarfjard and Kegl 1998, Baird and Dearden 2003). Under open-access conditions, increased value leads to uncontrolled competition for resources and destructive harvesting (Belcher and Schreckenberg 2007). In the NBR, the changes in C. strictum tenure and associated increases in harvest pressure and frequency appear to be influenced by a variety of factors as described below.

In some villages, the loss of $C$. strictum tenure and increase in harvest frequency appear to be driven in part by increased commercial demand. For example, in a previous study carried out with the Cholanaikens in Maancheery, harvesters discussed the ways in which individual $C$. strictum trees were marked and respected as belonging to specific 
Table 6. Comparison of two different resin collection practices on C. strictum. Values represent proportions. Numbers in parentheses represent the total number of trees.

\begin{tabular}{lccc}
\hline \hline & Incision & Resin collection practice & Chi Sq. \\
& Incision and Fire & \\
\hline Proportion of trees tapped 10-30 cm dbh $23 \%(14)$ & $100 \%(3)$ & $P=0.03$ \\
$\begin{array}{l}\text { Incisions with signs of bark recovery } \\
\text { after incision }\end{array}$ & $41 \%(216)$ & $20 \%(63)$ & $P<0.001$ \\
Incisions with termite attack & $11 \%(300)$ & $17 \%(75)$ & $P<0.001$ \\
\hline
\end{tabular}

individuals (Varghese 1992). In our interviews today, Maancheery residents said that this system began to be abandoned about 5 years ago when commercial demand increased. Other studies in the Western Ghats and elsewhere have also illustrated that increased demand tends to lead to more intense harvesting and overexploitation of NTFP (Muraleedharan et al. 2005, Marshall et al. 2006). However, in Maancheery, this was likely compounded by other social changes that were occurring at the same time. For example, in the previous study, harvesters commented that they were afraid of touching trees tapped by another person for fear of being affected by the spirits-but this belief has now waned, likely due to the breakdown of internal governance mechanisms and lack of new leaders.

The loss of tenure in Maancheery is likely also influenced by the village's total dependence on forest produce for their livelihoods and the pressure their forests receive from outside (illegal) harvesters (Table 4). This has led to a relatively high number of harvesters. In contrast, the villages of Alakal and Apaankaapu, which have maintained tenure while increasing their resin production, do not experience pressure from outside harvesters and the number of people who harvest is low as most of the village is engaged in other livelihood options (Table 4).

Low commercial demand and relatively low populations of harvesters may also be reasons that harvesters in Coonoor region continue to maintain their tenure systems. However, economic motivation is another important contributing factor: the price that harvesters from this region receive for
Grade 1 resin is nearly twice that for Grade 2 resin (Table 3).

Decreasing land bases may be another driving factor behind changes in tenure practices. The heavy harvest and low-grade resin obtained in the villages of Semenarai and Dhalamukh today likely reflect the fact the forests these villages have harvest rights to are under severe threat from the expansion of tea estates (Table 4). Consequently, the population of trees available to harvest is decreasing and longterm access to forest areas is insecure.

Traditional knowledge and experience also contribute to differences in tenure systems. For example, the fact that the Paniyas do not have a tenure system for $C$. strictum and harvest only lowquality resin is likely because they have only just entered the resin trade now that demand has increased.

Finally, in the NBR as elsewhere (Belcher and Schreckenberg 2007), government policy also appears to play a role. Here, differences in the legality of $C$. strictum harvest between Tamil Nadu and Kerala have resulted in very different trade routes. The lack of economic reward in Kerala for producing Grade 1 resin (Table 3) discourages harvest practices that foster its production.

\section{Differences in Ecological Impacts among Tapping Strategies}

The variation in timing and frequency of harvest within each of the three broad tapping strategies for 
Fig. 8. Size-class structure of $C$. strictum populations subject to different types of resin collection strategies. $n=8$. Error bars represent $\pm 1 \mathrm{SE}$.

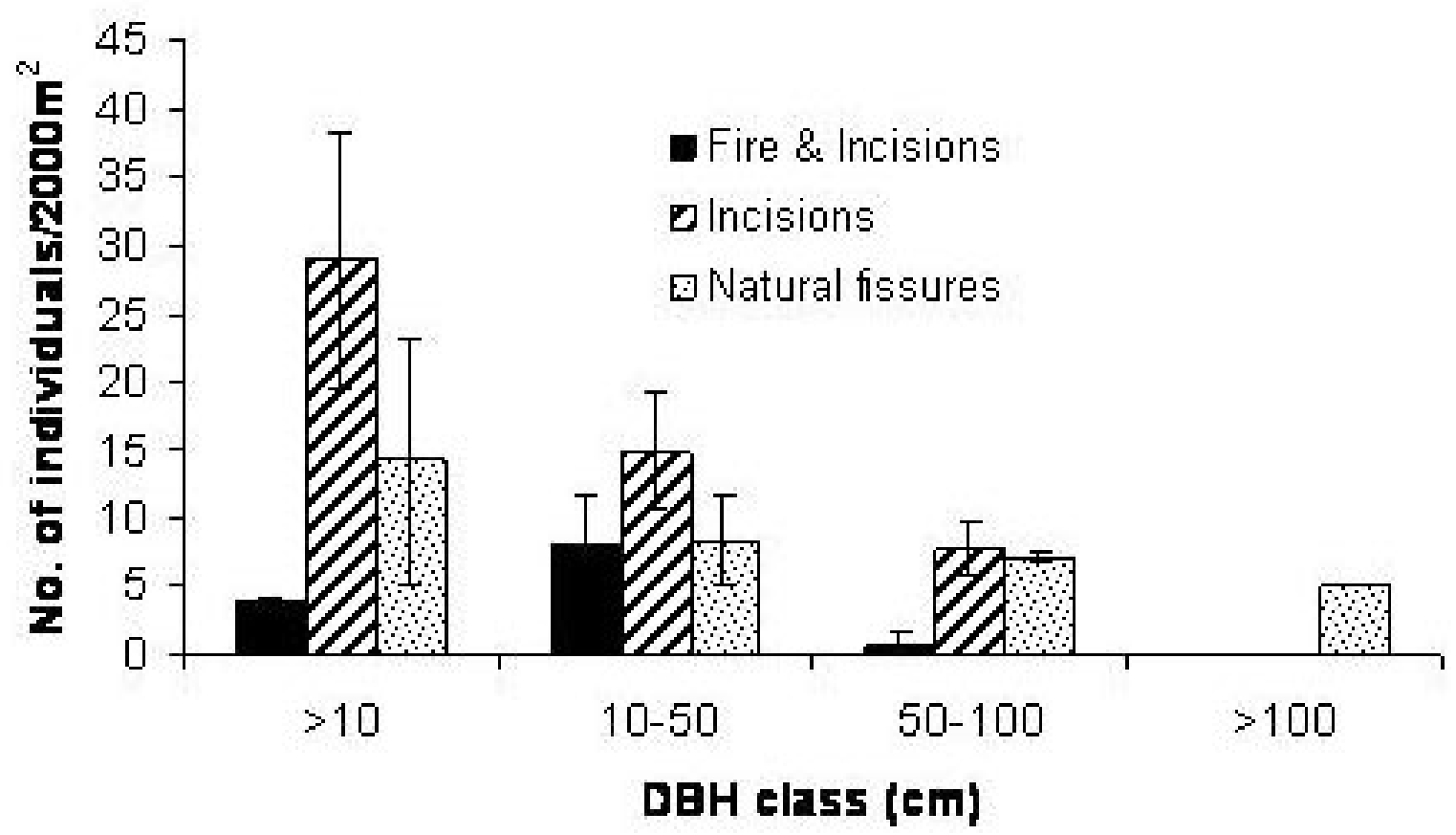

C. strictum make it difficult to compare differences in their ecological impacts. Nonetheless, our data illustrate some important trends. The finding that populations where resin is collected from natural fissures had significantly more large trees than those subject to either type of tapping suggests that heavy tapping may increase adult mortality. The total lack of large individuals in the populations subject to incisions and fire indicates that fire likely further increases adult mortality. Although $20 \%$ of trees in the populations harvested from natural fissures measured more than $100 \mathrm{~cm} \mathrm{dbh}$, the largest trees in the populations subject to tapping and tapping and fire were only $91 \mathrm{~cm}$ and $55 \mathrm{~cm}$ dbh, respectively. The fact that we would expect the opposite trends based on environmental differences among the sites adds support to this finding. That is, the populations subject to fire tapping occur in Nilambur region, which has the lowest elevation, highest rainfall, and tallest forest canopy (Table 1). In this region, canopy trees like $C$. strictum tend to grow to much larger sizes than they do in the upper elevations of Coonoor and Kotagiri. Given that all sites were heavily logged in the past, our results are not likely compounded by any differences in logging history.

Our results also illustrate that tapping using incisions leads to significantly higher probabilities of termite attack than collecting resin from natural fissures, and that the negative impacts are greater when fire is used. Similarly, fire appears to promote significantly slower and/or lower rates of recovery of the wounds made by the incisions (this could also be a result of the larger incisions that are a part of the fire-tapping strategies). Both of these could lead to earlier adult mortality in tapped trees. Field observations of harvest of Shorea javanica resin (Dipterocarpaceae) in Sumatra indicate that heavy tapping can lead to premature death (Torquebiau 1984).

The interpretation of our ecological results is limited by our low sample sizes, which were a consequence of the low natural densities of this species (Mathachen et al. 2005). However, they are strongly 
Fig. 9. Size-class distribution of incisions made for tapping $C$. strictum trees under two different resin collection strategies. $n=281$.

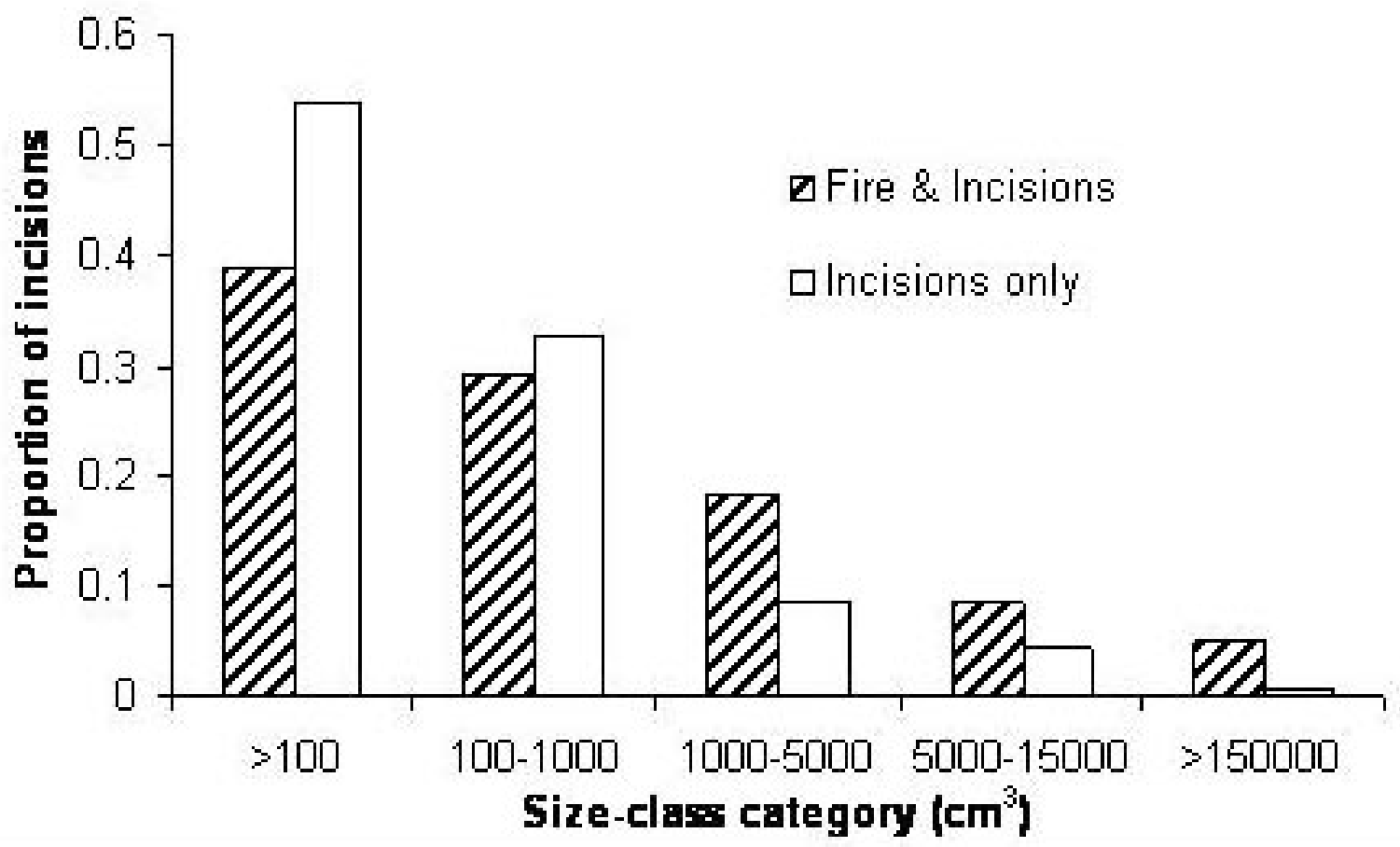

supported by the fact that they coincide with the observations of $C$. strictum harvesters. Harvesters all reported a decline in large trees, which they say fall more easily in the wind once they have been tapped heavily and especially tapped using fire. The use of fire at the base of $C$. strictum trees can damage the wood and lead to a portion of the base of the tree caving in or hollowing out. Fire can, therefore, make the trees more susceptible to being blown down in storms, thereby increasing adult mortality. Indeed harvesters who use fire and incisions remarked that once this tapping regime is initiated, the trees only survive for a few years. The results also coincide with observations made elsewhere in the Western Ghats that $C$. strictum trees subject to fire and incisions appear to suffer heavy rates of mortality, especially in heavy winds (Kannan 1992, Augustine and Krishnan 2006).

Given that tapping using incisions increases resin flow, our results could be explained by a trade-off between increased investment in resin production in tapped trees and decreased allocation of carbon resources to growth and reproduction, as has been hypothesized for other species (Rijkers et al. 2006). In addition, harvesters maintain that fire stimulates more resin production and our results show that fire allows for resin production in younger trees. If fire increases resin production, then the impacts of fire tapping can be expected to be greater.

The extra resources needed for increased resin production have implications for the timing of resin tapping. Resin harvest right before or during leaf flushing or flowering and fruiting might be expected to have the greatest impact as this is when demand for carbon resources is high. Similarly, resin tapping during the dry season, when $C$. strictum leaves are shed and are no longer photosynthesizing may also have high impacts. The ecological impacts of tapping resin during the monsoons (as practiced in some villages in the NBR) vs. other times of year warrants further investigation.

Another potential impact of heavy tapping is a decrease in reproductive output. Heavy tapping of 
Boswellia papyrifera in Ethiopia was found to significantly decrease rates of flower and fruit production and increase production of non-viable seeds (Rijkers et al. 2006). In this study, we observed regeneration of seedlings and saplings across all harvest types and regions. In addition, we probably underestimated seedling and sapling densities because $C$. strictum also regenerates outside of existing patches and in forest gaps and along riversides. Nonetheless, our preliminary investigations have illustrated that the proportion of C. strictum fruits that produced two viable seedlings (vs. only one) is significantly higher in trees that do not produce resin than in seeds that do (one-way ANOVA, $n=90$ fruits, $\mathrm{df}=1, p=0.004$; Varghese and Ticktin, unpublished data). This suggests that increased resin production in $C$. strictum caused by tapping could impact reproductive output.

Decreases in C. strictum reproductive output and in population size could have impacts on the other organisms who also depend on the species, such as pollinators and frugivores. For example, $C$. strictum is reported to be dispersed by large birds (Ganesh and Davidar 2001), including some species of endangered hornbills (Kannan 1992), which could be impacted by declining food sources. The harvest of Euterpe edulis palm hearts in Brazil has been shown to negatively affect the abundance of large frugivorous birds known to eat $E$. edulis fruits (Galleti and Aleixo 1998). Future research assessing the impacts of different tapping methods and intensities on reproductive output is needed.

\section{Implications for Sustainable Use Strategies}

Our results illustrate that $C$. strictum resin quality is determined by the frequency of tapping and that resin quality is, therefore, an indicator of harvest sustainability. They show that increased tapping frequencies occur where tenure systems have disappeared, and that this appears to be related to different combinations of factors, including increased commercial demand for resin, habitat loss due to forest encroachment, lack of economic incentives for high-grade resin, increased populations of harvesters, and the breakdown of traditional knowledge and beliefs. Tapping with incisions, and especially incisions and fire, appears to decrease adult survival, and the harvesters and traders we interviewed generally reported decreasing $C$. strictum populations, increasing harvest frequencies, and decreasing quality, and production of resin. Ecological surveys elsewhere have also suggested population decline (Ravikumar and Ved 2000, Augustine and Krishnan 2006) and decreased sizes of $C$. strictum populations could lead to still smaller populations over the long term. Tambat et al. (2005) found higher mortality of $C$. strictum seedlings planted from seeds collected from smaller groves than those collected from larger groves and hypothesized this to be due to greater inbreeding and accumulation of developmental lethals in the smaller groves.

Under current legislation in both Tamil Nadu and Kerala states, $C$. strictum trees, therefore, appear to be at risk. Clearly, the ban on trade of $C$. strictum in Tamil Nadu has not prevented commercial harvest of this species. Moreover, given that an important part of the demand for $C$. strictum is for spiritual use, and the reverence with which $C$. strictum resin was spoken of in our interviews, it is clear that any legislation prohibiting the sale of $C$. strictum will not easily stop such a deeply entrenched ritual. At the other extreme, Kerala has an open policy on harvest of resin and does not provide any regulations on quality, quantity, or method of harvest. Our results point to several avenues for improving conservation of $C$. strictum.

(1) The promotion and/or regulation of the sale of only high-grade (Grade 1 or Grade 2) resin would necessarily ensure a low intensity and frequency of harvest. In addition, high-grade resin does not contain bark (which comes with destructive harvesting) or contaminants of other species' resin. Increasing product quality has been illustrated to be an effective strategy to increase sustainability in other species (Cunningham 2001). Our crossregional comparison illustrated that, under the right tenure conditions, high-quality $C$. strictum resin can be obtained from all three of the tapping strategies. When demand is high, this will require the maintenance or re-strengthening of tenure systems.

(2) Increasing the amount of trees available by outplanting in forests and homegardens would decrease pressure on existing trees and help address the causes of tenure loss, especially in those villages whose forests are decreasing due to encroachment and where both demand and number of harvesters is increasing. When populations are low and demand and competition among harvesters high, intensification through management and cultivation is the only way to increase quantities (Belcher and Schreckenberg 2007). Although there is no 
demographic information currently available for $C$. strictum, our preliminary research indicates that increasing populations through planting is feasible. Canarium strictum has high rates of germination (close to 70\%) and fast rates of growth: seedlings planted from seed in community nurseries and then outplanted to fields measured about $3.6 \mathrm{~m}$ high with $\mathrm{dbh}=8 \mathrm{~cm}$, after 5 years (Varghese and Ticktin, unpublished data). These young trees have not flowered but already show signs of resin production from natural fissures on the bark.

The increased planting of trees would also be particularly important in regions where fire is used. Fire has been used by adivasis in Kerala over generations to tap $C$. strictum trees and fire is also commonly used to promote resin flow in Dipterocarp species in Southeast Asia-although its mode of use is different as the resin of those species is produced in the wood, not the bark (Ankarfjard and Kegl 1998, Baird and Dearden 2003). Under strict tenure, fire and tapping frequencies are low, and as fire appears to promote resin production, it likely leads to higher resin yields than the other tapping strategies, at least over the short term. Nonetheless, the higher adult mortality associated with this system, particularly in those regions where tapping frequency and intensity are now high, must be compensated for by increased rates of regeneration.

(3) Increasing the economic value of high-grade resin through added value and/or local certification would provide important incentives for sustainable harvest. Canarium strictum harvesters sell Grade 1 resin in those regions where its price is high. The Keystone Foundation has effectively increased the price paid to harvesters of sustainably harvested honey in the NBR though local certification and added value, leading to improvements in honeyharvesting techniques (Keystone Foundation 2007).

(4) Encouraging the sparing of some trees that are not tapped, in all populations, could help ensure adequate production of fruits, which may be important both for regeneration as well for other species that may depend on the fruit.

Finally, further research will be critical for identifying and developing more sustainable and higher yielding tapping strategies. Studies on the timing and frequency of $C$. strictum tapping and its relationships to growth, reproduction, and resin yields will be key. Research on the most appropriate tools used for tapping will also be important; the sustainability of resin tapping of Commiphora wightii in India has been improved by the development of a special knife for tapping (Bhatt et al. 1989).

This study employed a cross-disciplinary and regional approach to detect the current range of harvest practices for $C$. strictum, identify some of the social and economic factors that influence them, and provide insight on their differential ecological impacts. Putting the results together provided insight on conservation strategies. More comparative studies carried out on a regional scale that include both social and ecological analyses will allow us to gain better insight into the current status of other NTFP, and to better foster effective strategies for their management and conservation.

Responses to this article can be read online at:

http://www.ecologyandsociety.org/voll3/iss2/art11/responses/

\section{Acknowledgments:}

We are grateful to all the NBR harvesters, traders, and community members who participated in this study and generously shared their knowledge and time with us. We also thank B. Arpana and colleagues at Keystone Foundation for their help with the fieldwork. We are grateful to R. Ganesan of Ashoka Trust for Research in Ecology and the Environment and Tony Cunningham for their help and insight and to Sarah Dalle and two anonymous reviewers for helpful comments on previous versions of this manuscript. We thank the International Development Research Centre (IDRC), who provided financial support to People and Plants International (PPI) for this study. This was work was also supported by NSF grant OISE03-52827.

\section{LITERATURE CITED}

Ankarfjard, R., and M. Kegl. 1998. Tapping oleoresin from Dipterocarpus alatus (Dipterocarpaceae) in a Lao village. Economic Botany 52(1):7-14. 
Augustine, J., and P. G. Krishnan. 2006. Status of the black dammar tree (Canarium strictum Roxb) in Periyar Tiger Reserve, Kerala and the uses of black dammar. Indian Forester 132(10):1329-1335

Baird, I., and P. Dearden. 2003. Biodiversity conservation and resource tenure regimes - a case study from NE Cambodia. Environmental Management 35(5):541-550.

Belcher, B., and K. Schreckenberg. 2007. Commercialisation of non-timber forest products: a reality check. Development Policy Review 25 (3):355-377.

Berkes, F. 1999. Sacred ecology: traditional ecological knowledge and resource management. Taylor and Francis, Philadelphia, Pennsylvania, USA.

Bhatt, B. R., N. M. B. Nair, and H. Y. Mohan Ram. 1989. Enhancement of oleo-resin gum production in Commiphora wightii by improved tapping technique. Current Science 58(7):349-357.

Cunningham, T. 2001. Applied ethnobotany: people, wild plant use and conservation. Earthscan Publications Ltd., London, UK.

Gadgil, M., F. Berkes, and C. Folke. 1993. Indigenous knowledge for biodiversity conservation. Ambio 22:151-156.

Galletti, M., and A. Aleixo. 1998. Effects of palm heart harvesting on avian frugivores in the Atlantic rainforest of Brazil. Journal of Applied Ecology 35:286-293.

Gamble, J. S. 1935. Flora of the presidency of Madras. Vol 1. Adlard and Son Ltd., London, UK.

Ganesh, T., and P. Davidar. 2001. Dispersal modes of tree species in the wet forests of southern Western Ghats. Current Science 80(3):394-399.

2005. Fruiting phenology and pre-dispersal seed predation in a rainforest in southern Western Ghats, India. Pages 139-154 in J. L. Dew and J. P. Boubli, editors. Tropical fruits and frugivores: the search for strong interactors. Springer, Dordrecht, The Netherlands.
Ganeshaiah, K. N., R. U. Shaanker, K. S. Murali, U. Shankar, and K. S. Bawa . 1998. Extraction of non-timber forest products in the forest of Bilingiri Rangan Hills, India. 5. Influence of dispersal mode on species response to anthropogenic pressures. Economic Botany 52:316-319.

Gebrehiwot, K., B. Muys, M. Haile, and R. Mitloehner. 2003. Introducing Boswellia papyrifera (Del.) Hochst and its nontimber forest product, frankincense. International Forestry Review 5:348353.

Ghimire S. K., D. McKey, and Y. AumeeruddyThomas. 2005. Conservation of Himalayan medicinal plants: harvesting patterns and ecology of two threatened species, Nardostachys grandiflora D.C. and Neopicrorhiza scrophulariiflora (Pennell) Hong. Biological Conservation 124:463-475.

Kala, C. P. 2000. Status and conservation of rare and endangered medicinal plants in the Indian transHimalaya. Biological Conservation 93(33):371379.

Kannan, R. 1992. Burning out the black dammar, Canarium strictum Roxb. Bombay Journal of Natural History 91(1):159.

Keystone Foundation. 2007. Honey trails in the Blue Mountains. Keystone Foundation, The Nilgiris, Tamil Nadu, India.

Kusters, R. A., B. Belcher, and M. Ruiz Pérez. 2006. Balancing development and conservation? An assessment of livelihood and environmental outcomes of nontimber forest product trade in Asia, Africa, and Latin America. Ecology and Society 11 (2): 20. [online] URL: http://www.ecologyandsociety. org/vol11/iss2/art20/.

Langenheim, J. 2003. Plant resins: chemistry, evolution, ecology, ethnobotany. Timber Press, Portland, Oregon, USA.

Marshall, E., K. Schreckenberg, and A. C. Newton, editors. 2006. Commercialization of nontimber forest products: factors influencing success: lessons learned from Mexico and Bolivia and policy implications for decision-makers. UNEP World Conservation Monitoring Centre, Cambridge, UK. 
Mathachen, G. P., R. Vasuda, H. C. Hombe Gorda, K. N. Ganeshaiah, and R. Uma Shaanker. 2005. Ecological amplitude and regeneration of medicinally important threatened trees in the central Western Ghats. Indian Forester 130 (11):13301338.

Muraleedharan, P. K., N. Sasidharan, and B. M. Kumar. 2005. Non-timber forest productions in the western Ghats of India: floristic attributes, extraction and regeneration. Journal of Tropical Forest Science 17(2):243-257.

Murali, K. S., U. Shankar, R. R.Shanker, K. N. Ganeshaiah, and K. S. Bawa. 1996 Extraction of non-timber forest products in the forests of Biligiri Rangan Hills, India. 2. Impact of NTFP extraction on regeneration, population structure, and species composition. Economic Botany 50:252-269

Myers, N., R. A. Mittermeier, C. G. Mittermeier, G. A. B. Da Fonseca, and J. Kent. 2000. Biodiversity hotspots for conservation priorities. Nature 403:853.

Nantel, P., D. Gagnon, and A. Nault. 1996. Population viability analysis of American ginseng and wild leek harvested in stochastic environments. Conservation Biology 10:608-621.

Nepstad, D. C., and S. Schwartzman, editors. 1992. Non-timber product from tropical forest: evaluation of a conservation and development strategy. The New York Botanical Garden, Bronx, New York, USA.

Paudel, S., and K. F. Wiersum. 2002. Tenure arrangements and management intensity of butter tree (Diploknema butyracea) in Makawanpur district, Nepal. International Forestry Review 4 (3):223-230.

Phillip, M. A., and R. B. Croteau. 1999. Resinbased defenses in conifers. Trends in Plant Science 4:184-190.

Prabhakar, R. 1994. Resource use, culture and ecological change: a case study of the Nilgiri Hills of southern India. Dissertation, Indian Institute of Science, Bangalore, India.

Ravikumar, K., and D. K. Ved. 2000. Illustrated field guide-100 red listed medicinal plants of conservation concern in southern India. Foundation for the Revitalisation of Local Health Traditions (FRLHT), Bangalore, India.

Rijkers, T., W. Ogbazghi, M. Wessel, and F. Bongers. 2006. The effect of tapping for frankincense on sexual reproduction in Boswellia papyrifera. Journal of Applied Ecology 43(6):11881195.

Secretariat of the Convention on Biological Diversity (SCBD) 2001. Sustainable management of non-timber forest resources. CBD Technical Series 6. Secretariat of the Convention on Biological Diversity, Montreal, Quebec, Canada.

Sinha, A., and K. S. Bawa. 2002. Harvesting techniques, hemiparasites and fruit production in two non-timber forest tree species in south India. Forest Ecology and Management 168:289-300.

Sinha, A., and S. Brault. 2005. Assessing sustainability of nontimber forest product extraction: how fire affects sustainability. Biodiversity and Conservation 14:3537-3563.

Tambat, B., G. Rajanikanth, G. Ravikanth, R. Uma Shaankar, K. N. Ganeshaiah, and C. G. Kushalappa. 2005. Seedling mortality in two vulnerable tree species in the sacred groves of Western Ghats, South India. Current Science 88:350-352.

Ticktin, T. 2004. The ecological consequences of harvesting non-timber forest products. Journal of Applied Ecology 41(4):11-21.

Ticktin T., P. Nantel, F. Ramírez, and T. Johns. 2002. Effects of variation on harvest limits for nontimber forest species in Mexico. Conservation Biology 16(3):691-705.

Ticktin, T., and T. Johns. 2002. Chinanteco management of Aechmea magdalenae (Bromeliaceae): implications for the use of TEK and TRM in management plans. Economic Botany 56:43-57.

Torquebiau, E. 1984. Man-made dipterocarp forest in Sumatra. Agroforestry Systems 2:103-127.

Varghese, A.1992. Patterns in forest dependant lifestyles of the Cholanaicken-a hunter gatherer 
community of southern India. Thesis, Salim Ali School of Ecology, Pondicherry University, Pondicherry, India.

Vedeld P., A. Angelsen, E. Sjaastad, and G. K. Berg. 2004. Counting on the environment: forest incomes and the rural poor. Environmental Economics Series No. 98, International Bank for Reconstruction and Development (IBRD), Washington, D.C., USA. 